\title{
Mass upstream dispersal of pelagic-broadcast spawning cyprinids in the Rio Grande and Pecos River, New Mexico
}

\author{
Thomas P. Archdeacon ${ }^{1}$,, Stephen R. Davenport ${ }^{1}$, Joshua D. Grant ${ }^{1}$, and Eileen B. Henry ${ }^{1}$ \\ ${ }^{1}$ United States Fish and Wildlife Service, New Mexico Fish and Wildlife Conservation Office, \\ 3800 Commons Avenue NE, Albuquerque, NM 87109
}

\begin{abstract}
Pelagic-broadcast spawning minnows are a reproductive guild of fishes, of which several species occur in the American Great Plains and Southwest. The eggs and larvae of these species drift laterally and downstream, with drift distances varying depending on channel conditions and flow. Persistence or recolonization of these species in upstream reaches must depend on retention of eggs and larvae or upstream dispersal of later life stages, otherwise net downstream displacement of eggs and larvae would result in upstream extirpations. However, only a few individuals of several species have been observed dispersing. Here, we describe 2 direct visual observations of the young-of-year of 4 species of pelagic-broadcast spawning minnows dispersing upstream en masse. In August 2009, we observed Plains Minnow (Hybognathus placitus), Speckled Chub (Macrhybopsis aestivalis), and Rio Grande Shiner (Notropis jemezanus) dispersing upstream. The continuous shoal of fish was $>200 \mathrm{~m}$ in length and was dispersing upstream at a rate of $>1000$ fish/min. In July 2017, we observed a continuous shoal of Rio Grande Silvery Minnow (Hybognathus amarus) approximately $1.9 \mathrm{~km}$ in length dispersing upstream at a rate between 350 and $1500 \mathrm{fish} / \mathrm{min}$. While such dispersal events are rarely observed, they may be important for maintenance of populations in upstream areas.
\end{abstract}

RESUMEN.-Los peces reproductores pelágicos son un gremio reproductivo de peces, de las cuales, varias especies se encuentran en las Grandes Llanuras y al Sudoeste de América. Los huevos y las larvas de estas especies se desplazan lateralmente y río abajo, la distancia de su desplazamiento varía según el flujo y las condiciones del canal. La persistencia o recolonización de estas especies río arriba depende de la retención de huevos y larvas, o de la dispersión de estadios de vida posteriores río arriba; de lo contrario, el desplazamiento río abajo de huevos y larvas resultaría en su eliminación en la parte ascendente del río. Sin embargo, sólo pocos individuos de varias especies han sido observados desplazándose. En este estudio, describimos dos observaciones directas de juveniles de cuatro especies de peces dispersándose en masa río arriba. En agosto del 2009, observamos a Hybognathus placitus, Macrhybopsis aestivalis y Notropis jemezanus, dispersándose río arriba. El continuo cardumen de peces fue $>200 \mathrm{~m}$ de longitud y se desplazaba ascendentemente a una tasa de $>1000$ peces/min. En julio del 2017, observamos un cardumen continuo de aproximadamente $1.9 \mathrm{~km}$ de longitud desplazándose río arriba a una tasa de 350-1500 peces/min. Aunque, estos casos de desplazamiento son raros de observar, son importantes para el mantenimiento de la población en las áreas ascendentes del río.

A freshwater reproductive guild of cyprinid fish (Cyprinidae) known as pelagic-broadcast spawning minnows (sensu Balon 1975, 1981) inhabits sand-bed streams of the American Great Plains and Southwest (Hoagstrom et al. 2011, Hoagstrom and Turner 2015). This reproductive mode was first reported by Moore (1944) and is common among the endemic minnows of the region (Platania and Altenbach 1998). Nearly all pelagic-broadcast spawning minnows are declining due to various reasons, such as channel desiccation, flow regime changes, changes in precipitation patterns, channelization, and fragmentation
(Hoagstrom and Turner 2015, Perkin et al. 2015, Haworth and Bestgen 2017, Lehner et al. 2017). Fragmentation and changes in channel morphology are likely important causes of decline (Alò and Turner 2005), as the eggs of these minnow species are nonadhesive and passively drift in the stream (Platania and Altenbach 1998, Bestgen et al. 2016). Eggs drift laterally and downstream (Platania and Altenbach 1998, Dudley and Platania 2007), with drift distances prior to hatching depending on water velocity, channel morphology, water temperature, salinity, and suspended solids. Contemporary drift distances are likely

*Corresponding author: thomas_archdeacon@fws.gov 
much longer compared to historical drift distances because of increased channelization, changes in flow regime, and lack of habitats to entrain and retain eggs and drifting larval fish (Dudley and Platania 2007, Widmer et al. 2012, Medley and Shirey 2013).

Although historical drift distances of eggs and larvae may have been shorter than contemporary distances, the eggs and larvae of these species are exposed to constant unidirectional drift. Recolonization and persistence of these species in upper stream reaches must depend on retention of at least some eggs or upstream dispersal of later life stages, otherwise net downstream displacement of eggs and larvae would result in upstream extirpations (Fausch and Bestgen 1997). Known as the "drift paradox," persistence of macroinvertebrates in upper reaches of streams in spite of downstream drift of eggs and larvae was noted by Müller (1954) and could be explained by upstream migration of aerial adult life stages. However, not all aquatic macroinvertebrates have aerial adult stages, and persistence must be accomplished by another mechanism. Computer simulations suggest that the drift paradox in these species can be explained by density dependence and small-scale (e.g., <10 m) upstream movements (Anholt 1995, Humphries and Ruxton 2002). The resolution of the drift paradox by density dependence and upstream dispersal events may apply to pelagic-broadcast spawning minnows' life-history strategies as well. However, there are few observations of these fishes actually dispersing. Here, we describe 2 direct visual observations of pelagic-broadcast spawning minnows moving upstream en masse.

On 18 August 2009, we (TPA and SRD) observed upstream movement of a large number of pelagic-broadcast spawning minnow species in the Pecos River near Lake Arthur in southern Chaves County, New Mexico. Upon arriving at the site, we noticed a column of small fishes moving upstream in the margin of the stream. We used several timed counts of fish moving past a fixed point to extrapolate a movement rate of approximately 1800 fish/min. The water depth was $0.11 \mathrm{~m}$ where the fish were moving. The fish moved into and through a large shoreline pool. We determined that the shoal of fish extended at least $200 \mathrm{~m}$ upstream, but we made no effort to determine the full linear extent of the shoal.
The shoal of fish continued moving during our entire sampling period of $70 \mathrm{~min}$. We collected fish by seining into the shoal of moving fish, collecting 6 Rio Grande Shiner (Notropis jemazanus) ranging in standard length $(\mathrm{SL})$ from 24 to $26 \mathrm{~mm}$, a single Speckled Chub (Macrhybopsis aestivalis) at $22 \mathrm{~mm} \mathrm{SL}$, and a single nonnative Plains Minnow (Hybognathus placitus) at $32 \mathrm{~mm} \mathrm{SL}$; all were young-of-year fishes based on length (Taylor and Miller 1990, Horwitz et al. 2011). We also seined into the shoal of fish with a $3.0 \times 1.8-\mathrm{m}$ flat seine $($ mesh size $=3.2 \mathrm{~mm})$ pulled through the pool (maximum depth $=0.61 \mathrm{~m}$ ). We subsampled the seine haul catch and preserved what we estimated to be approximately one-third of the total catch. We preserved 36 Red Shiner (Cyprinella lutrensis), which is not a pelagicbroadcast spawning species, 46 Plains Minnow, 1 Speckled Chub, and 2 Rio Grande Shiner, all of which belong to the pelagic-broadcast spawning guild (Platania and Altenbach 1998).

On 12 July 2017, we (TPA, EBH, JDG) observed a large shoal of Rio Grande Silvery Minnow (Hybognathus amarus) moving upstream in the Rio Grande on Bosque Del Apache National Wildlife Refuge, Socorro County, New Mexico. During our observation and collection activities for fish rescue during summer drying (see Archdeacon [2016] for a description), we encountered an area of continuous flow $>1.9 \mathrm{~km}$ long that was apparently supported by seepage from river banks. This area of continuous flow was bounded both upstream and downstream by areas of discontinuous flow (i.e., river drying). We observed a nearly continuous shoal of fish moving through shallow water $(0.04-0.06 \mathrm{~m}$ deep) that was connecting deeper pools (0.3-0.6 m deep). We collected fish as described above. Of the fish collected, we found 100\% Rio Grande Silvery Minnow in seine hauls of the fish moving between pools. These fish were collected alive and transported to areas with perennial flow. We also seined pools in the area of continuous flow and collected the typical species assemblage common to the Middle Rio Grande (Archdeacon et al. 2015), dominated by Common Carp (Cyprinus carpio) and Rio Grande Silvery Minnow. We used timed counts of fish moving past a fixed point to extrapolate numbers of fish moving, as described above, and to determine a swimming speed. Rio Grande Silvery Minnow counts ranged from 
approximately 400 to $1500 \mathrm{fish} / \mathrm{min}$ as fish swam about $0.2 \mathrm{~m} / \mathrm{s}$. The continuous shoal was observed for over an hour on 12 July 2017. These observations of upstream movement continued through 14 July 2017, though the continuous shoal of Rio Grande Silvery Minnow was only observed on 12 July 2017 . After 12 July 2017, smaller shoals (e.g., $<100$ to 1000 fish) were observed moving between pools all day during fish rescue activities, which took place for approximately 9 hours each day. From 12 July to 14 July, we moved approximately 46,000 Rio Grande Silvery Minnow, of which $>99.9 \%$ were young-ofyear (i.e., <35 mm SL). By 14 July 2017, the upstream-most pool of the segment contained thousands of dead or dying fish, consisting of Common Carp and Channel Catfish (Ictalurus punctatus). By 15 July 2017, discontinuous pools had formed in the area. At this time, collecting Rio Grande Silvery Minnow became more difficult. Also, we noted that very few fish were attempting to move upstream in the few areas where pools were still connected.

There is growing evidence of upstream dispersal in pelagic-broadcast spawning minnows, but observations of dispersal are rare in the literature for many reasons. Minnows generally live in turbid streams and are not easily visible. They are too small for telemetry, are too small in younger life stages to allow use of passive integrated transponder (PIT) tags (Archdeacon et al. 2009), and are generally short lived (Hatch 1985, Fausch and Bestgen 1997, Horwitz et al. 2011). Additionally, recapture rates from tagging studies are often too low to allow robust inferences on movement rates (Platania et al. 2003, Archdeacon and Remshardt 2012). Advances in technology (e.g., visible implant elastomer tags, PIT tags, otolith microchemistry) have allowed observations or inference of dispersal distances for some species. Platania et al. (2003) used visible implant elastomer tags to document upstream movement up to $25 \mathrm{~km}$ of Rio Grande Silvery Minnow, while Archdeacon and Remshardt (2012) used PIT tags to record movements of the same species up to 19.7 km upstream. Rio Grande Silvery Minnow are physiologically capable of even more extensive movements than observed in the wild (Platania et al. 2003, Bestgen et al. 2010, Archdeacon and Remshardt 2012). Although Flathead Chub (Platygobio gracilis) produce demersal eggs, the eggs are nonadhesive and passively drift downstream, similar to eggs of pelagic-broadcast spawning species (Bestgen et al. 2016). Flathead Chub moved as far as $33 \mathrm{~km}$ upstream in Colorado streams until impeded by barriers (Walters et al. 2014). In the Pecos River, New Mexico, otolith microchemistry studies determined that some individuals of Pecos Bluntnose Shiner (Notropis simus pecosensis) moved as far upstream as $56 \mathrm{~km}$ while others remained near natal areas. Finally, Arkansas River Shiner (Notropis girardi) and Plains Minnow moved upstream as far as $214 \mathrm{~km}$, and Peppered Chub (Macrhybopsis tetranema) moved as far as $52 \mathrm{~km}$ (Wilde 2016). Average movements were smaller for these 3 species, but all had net upstream movement (Wilde 2016). Increased numbers of fishes are often found below dams (Koster 1957, Bestgen and Platania 1990, 1991, Walters et al. 2014). However, we know of only one other direct visual observation of pelagicbroadcast spawning minnows dispersing upstream, which involved 45 Plains Minnow traveling $250 \mathrm{~m}$ upstream in $15 \mathrm{~min}$ (Fausch and Bestgen 1997). These rare "black swan" events are usually ignored, but should be considered for a better understanding of the species ecology and management (Nuñez and Logares 2012). Further, due to the difficulties in observing mass dispersals outlined above, these events may not be rare and may actually occur regularly.

Typically, dispersal, including long-distance dispersal, is regarded as an important process for species even if it occurs rarely (Trakhtenbrot et al. 2005). For example, growing research in marine ecology suggests that both retention of larvae and long-distance dispersal are important for the resilience of reef fishes (Jones et al. 2009). In the Rio Grande, several authors have dismissed the importance of upstream dispersal in pelagic-broadcast spawning minnows or altogether denied that it occurs. For example, Medley and Shirey (2013) suggested that the removal of barriers to fish passage was unnecessary, given that no evidence had been provided that Rio Grande Silvery Minnow engage in long-distance upstream migrations. Similarly, a review panel suggested that requirements for fish passage at barriers would have little benefit to Rio Grande Silvery Minnow because "they do not move en masse in migratory fashion" and 
exhibit only a few individual upstream dispersers whose potential importance to the population was discounted (PBS\&J 2011). Finally, some authors have suggested that if eventual upstream migration is the mechanism required to maintain population persistence, there should be some tangible evidence of it occurring (Noon et al. 2017). Failing to account for the importance of upstream dispersal potentially hinders recovery efforts by ignoring important ecological and natural history observations.

We note confusion over the terms "migration" and "dispersal" with regard to the life history of pelagic-broadcast spawning minnows (e.g., PBS\&J 2011, Medley and Shirey 2013, Noon et al. 2017), though we are not the first to recognize this (Platania et al. 2003, Ronce 2007, Semlitsch 2008). Dispersal is the permanent, one-way movement of individuals or propagules with potential for gene flow (Ronce 2007). Migration is the regular, directed movement of all or most of the individuals in a population between 2 different habitats (Wootton 1998, Semlitsch 2008). For broadcast spawning minnows, persistence in upper reaches appears to be accomplished through dispersal (Fausch and Bestgen 1997, Platania et al. 2003, Archdeacon and Remshardt 2012, Chase et al. 2015, Wilde 2016) but may involve migration to spawning areas (Walters et al. 2014). Regardless, barriers to fish movement impede both dispersal and migration.

One important consideration for management of pelagic-broadcast spawning minnows is the size of the fish we observed moving. In both the Pecos River and Rio Grande, we observed movements of young-of-year individuals. Swim tests have focused on adult Rio Grande Silvery Minnow (Bestgen et al. 2010), but studies of fish passage structures should consider the swimming capabilities of youngof-year fishes as well, because this life stage may be the most likely to disperse upstream. We suggest further research of the swimming capabilities of young-of-year pelagic-broadcast spawning minnows, as well as the frequency and importance of upstream dispersal events.

We report 2 direct visual observations of 4 species of pelagic-broadcast spawning minnows moving upstream en masse during low-flow events. Although the antecedent conditions differed, the water velocities and depths the fish were moving through were similar. Fish were exhibiting positive rheotaxis, but it is unclear whether there was an external stimulus, as the Pecos River observations occurred in a flowing river, while the Rio Grande observations occurred in a flowing but isolated stretch. Though it is conceivable that Rio Grande Silvery Minnow were moving upstream in response to stream drying, these particular individuals (at least 46,000) were trapped in an area that did not lead to perennial flow, and these fish would have perished if not translocated. Direct observations of small-bodied fish dispersing en masse are rarely recorded, but we advise against assuming without further research that these dispersal events do not occur and are unimportant to the population.

\section{ACKNOWLEDGMENTS}

The findings and conclusions in this article are those of the authors and do not necessarily represent the views of the U.S. Fish and Wildlife Service. We thank Jason Davis, Joel Lusk, Justin Reale, and 2 anonymous reviewers for constructive comments on the manuscript. All voucher specimens collected were accessioned into the Museum of Southwestern Biology, Department of Biology, University of New Mexico (catalog numbers 85822, 85823, 83801, and 83802 under ACC2006-V:23). Fish were collected under New Mexico Department of Game and Fish authorization number 1776 and Federal Fish and Wildlife permit TE676811-10. The work presented in this manuscript was partially funded by the U.S. Bureau of Reclamation, Albuquerque Area Office, New Mexico, Interagency Agreement R13PG40023.

\section{Literature Cited}

ALÒ, D., AND T.F. Turner. 2005. Effects of habitat fragmentation on effective population size in the endangered Rio Grande Silvery Minnow. Conservation Biology 19:1138-1148.

Anholt, B.R. 1995. Density dependence resolves the stream drift paradox. Ecology 76:2235-2239.

ARCHDEACON, T.P. 2016. Reduction in spring flow threatens Rio Grande Silvery Minnow: trends in abundance during river intermittency. Transactions of the American Fisheries Society 145:754-765.

Archdeacon, T.P., K.R. Henderson, T.J. Austring, and R.L. CoOK. 2015. Comparison of fish communities at random and nonrandom locations in a sand-bed river. North American Journal of Fisheries Management 35:578-585.

Archdeacon, T.P., and W.J. Remshardt. 2012. Observations of hatchery-reared Rio Grande Silvery Minnow 
using a fishway. North American Journal of Fisheries Management 32:648-655.

archdeacon, T.P., W.J. Remshardt, and T.L. Knecht. 2009. Comparison of two methods for implanting passive integrated transponders in Rio Grande Silvery Minnow. North American Journal of Fisheries Management 29:346-351.

BALON, E.K. 1975. Reproductive guilds of fishes: a proposal and definitions. Journal of the Fisheries Resources Board of Canada 32:821-864.

BALON, E.K. 1981. Additions and amendments to the classification of reproductive style in fishes. Environmental Biology of Fishes 6:377-389.

Bestgen, K.R., H.J. Crockett, M.R. Haworth, and R.M. FitZPATRICK. 2016. Production of nonadhesive eggs by Flathead Chub and implications for downstream transport and conservation. Journal of Fish and Wildlife Management 7:434-443.

Bestgen, K.R., B. Mefford, J.M. Bundy, C.D. Walford, AND R.I. Compton. 2010. Swimming performance and fishway model passage success of Rio Grande Silvery Minnow. Transactions of the American Fisheries Society 139:433-448.

Bestgen, K.R., and S.P. Platania. 1990. Extirpation of Notropis simus simus (Cope) and Notropis orca Woolman (Pisces: Cyprinidae) from the Rio Grande in New Mexico, with notes on their life history. Occasional Papers of the Museum of Southwestern Biology 6:1-8.

Bestgen, K.R., and S.P. Platania. 1991. Status and conservation of the Rio Grande Silvery Minnow, Hybognathus amarus. Southwestern Naturalist 36:225-232.

Chase, N.M., C.A. Caldwell, S.A. Carleton, W.R Gould, AND J.A. HobBs. 2015. Movement patterns and dispersal potential of Pecos Bluntnose Shiner (Notropis simus pecosensis) revealed using otolith microchemistry. Canadian Journal of Fisheries and Aquatic Sciences 72:1575-1583.

Dudley, R.K., and S.P. Platania. 2007. Flow regulation and fragmentation imperil pelagic-spawning riverine fishes. Ecological Applications 17:2074-2086.

Fausch, K.D., AND K.R. Bestgen. 1997. Ecology of fishes indigenous to the central and southwestern Great Plains. Pages 131-166 in F.L. Knopf and F.B. Samson, editors, Ecology and Conservation of Great Plains Vertebrates. Springer-Verlag New York, NY.

Hatch, M.D., W.H. Baltosser, and C.G. Schmitt. 1985. Life history and ecology of the Bluntnose Shiner (Notropis simus pecosensis) in the Pecos River of New Mexico. Southwestern Naturalist 30:555-562.

Haworth, M.R., and K.R. Bestgen. 2017. Flow and water temperature affect reproduction and recruitment of a Great Plains cyprinid. Canadian Journal of Fisheries and Aquatic Sciences 74:853-863.

Hoagstrom, C.W., J.E. Brooks, and S.R. Davenport. 2011. A large-scale conservation perspective considering endemic fishes of the North American plains. Biological Conservation 144:21-34.

Hoagstrom, C.W., and T.F. Turner. 2015. Recruitment ecology of pelagic-broadcast spawning minnows: paradigms from the ocean advance science and conservation of an imperilled freshwater fauna. Fish and Fisheries 16:282-299.

Horwitz, R.J., D.H. Keller, P.F. Overbeck, S.P. PlataNIA, AND R.K. DudLEy. 2011. Age and growth of Rio Grande Silvery Minnow. Final report submitted to the U.S. Bureau of Reclamation, Albuquerque, NM.
Humphries, S., And G.D. Ruxton. 2002. Is there really a drift paradox? Journal of Animal Ecology 71:151-154.

Jones, G.P., G.R. Almany, G.R. Russ, P.F. Sale, R.S. SteneCK, M.J.H. van OPPEN, AND B.L. Willis. 2009. Larval retention and connectivity among populations of corals and reef fishes: history, advances and challenges. Coral Reefs 28:307-325.

Koster, W.J. 1957. Guide to the fishes of New Mexico. University of New Mexico Press, Albuquerque, NM.

Lehner, F., E.R. Wahl, A.W. Wood, D.B. Blatchford, AND D. LLEWELLYN. 2017. Assessing recent declines in Upper Rio Grande runoff efficiency from a paleoclimate perspective. Geophysical Letters 44:4124-4133.

Medley, C.N., AND P.D. Shirey. 2013. Review and reinterpretation of Rio Grande Silvery Minnow reproductive ecology using egg biology, life history, hydrology, and geology information. Ecohydrology 6:491-505.

Moore, G.A. 1944. Notes on the early life history of Notropis girardi. Copeia 1944:209-214.

MüLLER, K. 1954. Investigations on the organic drift in North Swedish steams. Report to the Institute of Freshwater Research, Drottningholm 34:133-148.

Noon, B., D. Hankin, T. Dunne, and G. Grossman. 2017. Independent science panel findings report: Rio Grande Silvery Minnow key scientific uncertainties and study recommendations. Prepared for the U.S. Army Corps of Engineers, Albuquerque District, on behalf of the Middle Rio Grande Endangered Species Collaborative Program. Prepared by GeoSystems Analysis, Inc., Albuquerque, New Mexico; [accessed August 2017]. http://riograndeam.wiki spaces.com/RGSM + Panel+Workshop

NuñEZ, M.A., AND R. Logares. 2012. Black swans in ecology and evolution: the importance of improbable but highly influential events. Ideas in Ecology and Evolution 5:16-21.

PBS\&J. 2011. Scientific review report San Acacia fish passage. Prepared for the Middle Rio Grande Endangered Species Collaborative Program, U.S. Bureau of Reclamation, Albuquerque, NM; [accessed August 2017]. http://riograndeam.wikispaces.com/file/ view/PBS\%26J + 2011.pdf

Perkin, J.S., K.B. Gido, A.R. Cooper, T.F. Turner, M.J. Osborne, E.R. Johnson, and K.B. Mayes. 2015. Fragmentation and dewatering transform Great Plains stream fish communities. Ecological Monographs 85:73-92.

Platania, S.P., and C.S. Altenbach. 1998. Reproductive strategies and egg types of seven Rio Grande Basin cyprinids. Copeia 1998:559-569.

Platania, S.P., M.A. Farrington, W.H. Brandenburg, S.J. Gottlieb, And R.K. Dudley. 2003. Movement patterns of Rio Grande Silvery Minnow Hybognathus amarus in the San Acacia Reach of the Rio Grande during 2002. Final report submitted to U.S. Bureau of Reclamation, Albuquerque, NM.

Ronce, O. 2007. How does it feel to be a rolling stone? Ten questions about dispersal evolution. Annual Review of Ecology, Evolution, and Systematics 38:231-253.

SemLitsch, R.D. 2008. Differentiating migration and dispersal processes for pond-breeding amphibians. Journal of Wildlife Management 72:260-267.

TaYlor, C.M., and R.J. Miller. 1990. Reproductive ecology and population structure of the Plains Minnow, Hybognathus amarus (Pisces: Cyprinidae) in central Oklahoma. American Midland Naturalist 123:32-39. 
Trakhtenbrot, A., R. Nathan, G. Perry, and D.M. RICHARDSON. 2005. The importance of long-distance dispersal in biodiversity conservation. Diversity and Distributions 11:173-181.

Walters, D.M., R.E. Zuellig, H.J. Crockett, J.F. Bruce, P.M. Lukacs, and R.M. FitzPatrick. 2014 Barriers impede upstream spawning migration of Flathead Chub. Transactions of the American Fisheries Society 143:17-25.

Widmer, A.M., J.J. Fluder, J.W. Kehmeier, C.N. MedLEY, AND R.A. VALDEZ. 2012. Drift and retention of pelagic spawning minnow eggs in a regulated river. River Research and Applications 28:192-203.

WiLde, G.R. 2016. Migration of Arkansas River Shiner and other broadcast spawning fishes in the Canadian
River, New Mexico-Texas. Final report to the Great Plains Landscape Conservation Cooperative, Albuquerque, New Mexico; [accessed August 2017]. https://www.sciencebase.gov/catalog/item/5717d729 e4b0ef3b7caab927

Wootton, R.J. 1998. Ecology of teleost fishes. Second edition. Kluwer Academic Publishers, Dordrecht, The Netherlands.

Received 23 August 2017

Revised 13 November 2017 Accepted 15 November 2017 Published online 13 April 2018 